\title{
[South] Africa's Health System and Human Rights: A Critical African Perspective
}

\author{
${ }^{1}$ Kgothatso Brucely Shai, ${ }^{* 2}$ Olusola Ogunnubi \\ ${ }^{1}$ University of Limpopo, South Africa \\ 2Mangosuthu University of Technology, South Africa \\ *ogunnubi.olusola@mut.ac.za
}

\begin{abstract}
For more than two decades, 21 ${ }^{\text {st }}$ March has been canonised and celebrated among South Africans as Human Rights Day. Earmarked by the newly democratic and inclusive South Africa, it commemorates the Sharpeville and Langa massacres. As history recorded, on the $21^{\text {st }}$ March 1960, residents of Sharpeville and subsequently, Langa embarked on a peaceful anti-pass campaign led by the African National Congress (ANC) breakaway party, the Pan Africanist Congress of Azania (PAC). The pass (also known as dompas) was one of the most despised symbols of apartheid; a system declared internationally as a crime against humanity. In the post-apartheid era, it is expectedthat all South Africans enjoy and celebrate the full extent of their human rights. However, it appears that the envisaged rights are not equally enjoyed by all. This is because widening inequalities in the health-care system, in schooling, and in the lucrative sporting arena have not been amicably and irrevocably resolved. Furthermore, it is still the norm that the most vulnerable of South Africans, especially rural Africans, find it difficult, and sometimes, impossible to access adequate and even essential healthcare services. Central to the possible questions to emerge from this discourse are the following(i) What is the current state of South Africa's health system at the turn of 23 years of its majority rule? (ii) Why is the South African health system still unable to sufficiently deliver the socioeconomic health rights of most South African people? It is against this background that this article uses a critical discourse analysis approach in its broadest form to provide a nuanced Afrocentric assessment of South Africa's human rights record in the health sector since the year 1994. Data for this article is generated through the review of the cauldron of published and unpublished academic, official and popular literature.
\end{abstract}

Keywords: Afrocentricity, health system, human rights, South Africa

\section{Introduction}

The 21 $1^{\text {st }}$ March non-violent campaign against pass laws in South Africa was initially planned to take place on the $31^{\text {st }}$ March 1960 under the guidance of the ANC. This date was chosen for the purpose of giving more meaning and expression to the $31^{\text {st }}$ March anti-pass campaign that took place in the year 1919. However, when information about the ANC's plan to embark on a campaign for the total abolition of the pass laws on the 31st March 1960 leaked and reached PAC members, the leadership of PAC and its constituency decided to stage its own opportunistic campaign ten days before the ANC. This was done in order to take advantage of its tactical, strategic and political significance for the growth of the party that was founded in 1959. Despite the peaceful nature of the 'hijacked' campaign by the PAC, the police in both Sharpeville and Langa meted out violence by firing live ammunition on the protesters. As a result, 69 people were reportedly killed, and 180 others severely wounded in Sharpeville. In the case of Langa, three people were left dead while 26 others suffered serious injuries. There have been competing explanations by scholars and government officials about the Sharpeville and Langa massacre. An official account by the apartheid regime has been that the campaign in question agitated for violence and instability against the security establishment. It added that the chaotic manner in which police were provoked left them with no option but to crush the protest ruthlessly. On the contrary, the fact that the majority of the victims of Sharpeville and Langa massacres were not armed and were shot on their backs is evidence that they were peaceful. As a results, when charged with a harsh response, they also opted to run for cover, instead of fighting back(Pahad, 2014). While the dynamics of crucial historical events such as the Sharpeville and Langa massacres are contested across the political and academic divide, a quick cursory overview of the academic and popular literature reflects competing positions about post-apartheid South Africa's human rights record in the health sector. 
Globally, South Africa features prominently in most health care problems such as HIV/AIDS, Tuberculosis, maternal and child mortality, as well as obesity. These remain the leading cause of death (DEA, 2013). ${ }^{1}$ In South Africa, the health burden mostly affects the poor, with the majority of those affected unable to afford private health care services and therefore having to rely on the government for health care support. In over two decades of post-apartheid era, South Africa's mortality and morbidity profile of infectious and noncommunicable diseases have worsened considerably among all age groups(Kahn, 2011). Clearly, this calls for a rethinking of the philosophy underpinning the delivery of health care in South Africa and Africa generally. Admittedly, the National Development Plan 2030makes laudable recommendations on how to effectivelyimprove the socioeconomic determinants of health, address the imbalance that has resulted in unforgivable historical injustices and bridge the embedded inequality in the provision of health care(National Planning Commission, 2012). However, despite annual budgetary expenditure, little has been done to change the status quo in ways that guarantee the human rights of South Africans in such critical arenas as the health sector. It was envisaged that the political progress experienced in South Africa with the enthronement of liberal democracy in 1994 should ultimately translate into significant transformation in all aspects of societal life including the health sector. As Litch and de Villiers (1994, p. 1)projected, "the evidence of progresswe now see ranges from disheartening to uncertain". The present article considers the extent to which health care delivery is a guaranteed human right in South Africa.

As a socioeconomic right, health care is secured in the South African Constitution. Evans (2002, p. 197)explains that health as a human right is captured in the Tavistock Group's principle that, "the right to health cannot be bought and sold in the marketplace like other commodities. Nor can the right to health be limited by the ability to pay". Some scholars proffering a liberal consensus argue against a human right to health(Barlow, 1999). They contest the "definition and extent of both human rights and health care"(Evans, 2002, p. 197). The dominant narrative within the academic circles and the mainstream media is that South Africa's health system is in a crisis. The current crisis with the Life Esidimeni tragedy, which resulted in the death of over 94 mental health patients, is a constant reminder of a failing public health system (Kahn, 2011). Furthermore, in Africa, the Ebola virus disease (EVD) outbreak that started in the year 2013 and lasted until 2016 raises serious human rights question about the rife perception of the need to curb diseases originating in the global South from spreading to more prosperous regions and the powerlessness of the former to address this. Durojaiye and Mirugi-Mukundi $(2015$, p. 23) warn that Africa's right to health, guaranteed in several human rights instruments, is further compromised by the slowness of pharmaceutical companies in industrialised countries in developing a cure or vaccine for Ebola which "confirms the fact that these companies hardly invest in tropical or neglected diseases that may benefit millions of people in poor regions". The first part of this article details the general orientation of the study. Secondly, the methodological component of the study is advanced. Further sections reviewthe relevant literature on health and human rights focusing on South Africa. It also presents the legal framework in which health care is delivered in the country. The fourth section appraises South Africa's health sector in terms of securing the socioeconomic claims of health as a human right. The final part is the conclusion and policy implications.

\section{Methodological and conceptual issues}

It should be emphasized that the epistemic location of thisarticle is the Afrocentric paradigm, as propagated by scholars such as Asante (2003), Mazama (2003), Modupe (2003) and Alkebulan (2007). Afrocentricity is relevant for this discourse because most studies on this subject stem from a Euro-American standpoint and do not often correctly capture the qualitative imagery of the human rights discourse of Africa and very often neglect the political history of its people in general. This less considered missing link (Afrocentric perspective) offers deeper analytical rigour for understanding the policy machinery of African countries(Shai \& Molapo, 2017). Thisshould be understood within the context that policy analysis (and monitoring in particular) requires relevant, reliable and valid information. Flowing from this, Don K. Price makes a distinction between scientific estate, which seeks only to discover knowledge, and the professional estate, which strives to apply scientific knowledge to the solution of practical problems. Based on the foregoing, it is proposed that the African situation should be perceived, interpreted and understood in the first instance

\footnotetext{
${ }^{1}$ According to the NDP 2030 report, between 1998 and 2008, notification of deaths doubled, reaching a staggering 700,000 per year (NPC 2012).
} 
through an indigenous theoretical lens, tools and standards, if Africa is to find lasting solutions to challenges faced by its people and countries. This proposition finds a true and perhaps honest expression in the works of many African-centred scholars. For example, Richards (1979, p. 249)lends credence to the theoretical attitude and exposition of this article when she asserts that:

It would be the mission of African social scientists, at home and in the Diaspora, to devote their energies to the radical reconstruction of the disciplines in which theywere trained. Without such an approach, African peoples run the risk of incorporating the theoretical, mythological and ideological models of white social science into their own methodologies, thereby unknowinglyinternalisingthe values of western European society, including the negative image of Africa which white racialism and culturalism has created.In terms of the research design, this article is largely based on document analysis. Equally important, the current article emphatically projects human rights as the inherent and inalienable rights of the people in order for them to be treated with equality, dignity, and respect. Human rights are normally entrenched in law - whether international or national law - with the United Nations (UN) as the custodian for their promotion, protection, and realization. ${ }^{2}$ States, on the other hand, have a responsibility to ensure the enjoyment of human rights by all citizens. In essence, they are expected to make provision for the respect, promotion, and adherence of human rights into their domestic laws and policies. It should be taken into consideration that it is not every country in the world where these rights are respected and preserved(Shai \& Mothibi, 2015). As such, the analysis of this article deliberately uses South Africa as a test case to provide a nuanced Afrocentric appraisal of Africa's health system, as well as its connection with human rights in the post-Millennium Development Goals (MDGs) era. Although the focus of this article is on South Africa, it is argued that the country's human rights record in the health sector can be well understood if it is located within a broader African context.

\section{Legislative frameworks on Health Care: Between Theory and Practice}

There are widespread claims in the literature that there has been tremendous progress in the protection of human rights since the establishment of the UN and the Commission on Human Rights over 65 years ago(Evans, 2002). However, this discourse is often challenged by the reality of the deplorable health conditions in many African countries. Within government circles, it is believed that major strides have been made to provide better health services for all. Nevertheless, despite numerous policy provisions and budgetary spending on health care, as well as the guarantees of the Constitution enshrining basic health care as a fundamental human right, inadequate health care remains a lingering problem for many South Africans. Based on the preceding polarised views about these public health and human rights, this article seeks to expand the disciplinary engagement of South Africa's human rights record in the health sector using an Afrocentric perspective.

Chapter 2 of the South African 1996 Constitution, the Bill of Rights entrenches human rights in the country's national law. In terms of the provision of health, as part of these rights, Act 108, section 27 provides that: Everyone has the right to have access to - (a) health care services, including reproductive health care; The state must take reasonable legislative and other measures within its available resources, to achieve the progressive realisation of each of these rights.Read with section 9:(3), the supreme law of the country further asserts that"The state may not unfairly discriminate directly or indirectly against anyone on one or more grounds, including race, gender, sex, pregnancy, marital status, ethnic or social origin, colour, sexual orientation, age, disability, religion, conscience, belief, culture, language, and birth; No person may unfairly discriminate directly or indirectly against anyone on one or more grounds in terms of sub-section (3)".A number of policies further corroborate the constitutional provision guaranteeing the equality of health care access to South Africans. For instance, Chapter 10 of the National Development Plan 2030on "Promoting Health" articulates reform strategies aimed to achieve nine long-term health goals for South Africa, which includes the following:

- Increase average male and female life expectancy to 70 years

- Progressively improve TB prevention and cure

- Reduce maternal, infant and child mortality

\footnotetext{
${ }^{2}$ Article 12 of the International Covenant on Economic, Social and Cultural Rights (ICESCR)makes broad provisions guaranteeing the right to highest attainable standard of physical and mental health of every individual.
} 
- Significantly reduce prevalence of non-communicable chronic diseases

- Reduce injury, accidents and violence by 50 percent from 2010 levels

- Complete health systems reforms

- Primary healthcare teams provide care to families and communities

- Universal health care coverage

- Fill posts with skilled, committed and competent individuals(National Planning Commission, 2012)

However, the distinct overlap between equality and health rights immediately exposes ethical dilemma for an economically, culturally and sexually diverse society such as South Africa. As the NDP 2030 outlines, "The performance of South Africa's health system since 1994 has been poor, despite good policy and relatively high spending as a proportion of GDP"(National Planning Commission, 2012, p. 331).It is for this reason that part of the nine challenges that necessitated the development of the NDP 2030 included the failure of the public health system to meet the demand of the country and sustain quality. Related to this has been dwindling funding of the health sector, which shows a lack of prioritization of health as a critical aspect of national wellbeing. For example, budgetary allocation to health care relative to GDP over a period of seven years shows a declining trend of a chronically underfunded sector (see Table 1).

Table 1: South Africa's Government Health Expenditure 2007 - 2014

\begin{tabular}{llll}
\hline Year & Total (Rand million) & \% of GDP & \% of total government expenditure \\
\hline $2007 / 08$ & 71,439 & 3.4 & 13.9 \\
$2008 / 09$ & 85,154 & 3.7 & 14.0 \\
$2009 / 10$ & 99,468 & 4.1 & 13.8 \\
$2010 / 11$ & 109,769 & 4.1 & 14.1 \\
$2011 / 12$ & 122,427 & 4.2 & 14.7 \\
$2012 / 13$ & 132,165 & 4.0 & 14.7 \\
$2013 / 14$ & 140,721 & 4.0 & 14.6 \\
\hline
\end{tabular}

Source: Authors' compilation; see(National Planning Commission, 2012).

There is no gainsaying that like everyone else Lesbian, Gay, Bisexual, Transgender and Intersex (LGBTI) groups are also entitled to benefit from these rights and others, as enshrined in the Constitution and related laws of South Africa. However, the realities and practicalities in South Africa show a widening chasm between theoretical prescriptions of health delivery and practice in this regard. Indeed, despite extant laws guaranteeing the rights of the LGBTI community, it is common knowledge among most South Africans that the LGTBI populace in South Africa is often subjected to unfair discrimination, persecution, and violence for merely expressing who they are and who they choose to love. The foregoingshould be understood within the context of the Rational Comprehensive model of policy analysis; which explains that there are usually no societal values agreed upon. On the contrary, there are only benefits to specific groups and individuals, many of which are conflicting(Dunn, 2015).Since conflictingbenefits and costs cannot be compared or weighed, it is significant for the society, in general, to make certain ethical sacrifices and compromises for the sake of mutual and peaceful co-existence, stability, security, and development (Maake, 2009). While the literature on health and human right is rife and its study in South Africa is not new, not much research has been undertaken in this respect. For instance, scholars have researched on the dimension of South Africa's response to HIV as a human right issue. This raises the need for social and economic rights of the people to be promoted on the same level as the civil and political rights guaranteed in the Bill of Rights (Heywood \& Cornell, 1998).

\section{South Africa's health sector: Comparative national, continental and global prognosis}

The contemporary society and the Africa-West praxis manifest a double-edged sword. However, unlike the post-independent African state, the West and the United States of America (US) tendto interfere unnessarily in the affairs of other countries, as were the cases in Iraq (2003) and Libya (2011) (Poopedi, 2014; Shai, 2010). However, when it comes to their nationals, the US and other Western countries are generally delicate, kind and careful. In contrast, most African leaders are directly (and in complicit) cruel to their people. For example, Swaziland (current), Zimbabwe (2008) (Dzimiri, Runhare, Dzimiri, \& Mazorodze, 2014; Maleka \& 
Shai, 2016). This is an important point that distinguishes African leaders from Western leaders. The above discussion is corroborated by Onyeani (2012, p. 38)in his claim that "in Africa, we are totally undisciplined. We have leaders who are not ruthless with themselves in pursuit of excellence but who are quick being ruthless to their citizens".

Contextually, nationalist leaders have tried to win the hearts and minds of the masses to support the cauldron of the struggle against the inhumane and brutal systems of colonialism, imperialism and apartheid. In order to do so, these leaders made promises ranging from better education, gainful employment and decent medical health care in post-independence era and new democratic dispensation (as in the case of South Africa) (Khapoya 2010). It is for this reason that education, labour and health rights have been effected in the policy framework of the post-independent African state(Shai \& Molapo, 2017). Despitethis, severe contradictions are evident regardingthe seriousness of African states and governments in rolling out health services. Admittedly, health is an essentialsocioeconomic service in South Africa. However, in Africa as a whole, the health sector is riddled with structural problems relating to innovation, accessibility, and trade. In the African situation, respective national and provincial governments usually only show real commitment to the provision of health services when the effects of disasters such as HIV/AIDS and Ebola reach alarming proportions. Even then, Westerners typically lead mitigating efforts for addressing worsening health situations in South Africa and elsewhere in Africa. To make matters worse, even essential amenities used in South Africa/Africa's health facilities (such as antibiotics, injections and intravenous infusions) are often imported and without any remarkable effort to produce the same within the continent (Onyeani, 2012).

Lack of political will: The deplorable situation of Africa's health security is compounded by an already worse situation, exemplified for instance inlimited progress relating to the establishment of the only medical school to be established in the new democratic dispensation. Following the detachment of the Medunsa campus from the University of Limpopo, the new medical school was scheduled to be attached to the latter. According to government reports, the University of Limpopo medical school was opened for its first intake during the 2016 academic year(Quintal, 2016). However, as recent media reports about the medical school indicate, it is safe to state that there are serious structural weaknesses that make it impossible for the University to produce globally competitive medical doctors, at least in the short run. This distasteful situation is a disservice to aspiring medical doctors registered at the institution. It is also a dream deferred for the communities in Limpopo province, who had pinned their hopes on the University of Limpopo's medical school to produce locally relevant and globally competitive medical doctors, to ameliorate the critical shortages of senior medical staff at public hospitals.It would appear that the failure of the government to ensure that the medical school at the University of Limpopo (a $2^{\text {nd }}$ historically disadvantaged university earmarked for the training of medical doctors) is established to the level of full functionality can be partly attributed to the fact that the manner in which it was launched was driven by less political will and developmental commitment. Furthermore, its establishment was prompted by a desperate desire to score cheap political points for the governing ANC and quench the selfish interests of certain individuals who stood to financially benefit from this project by doing business with the University either legally or illegally. It is also not a far-fetched idea that the performance bonuses of the university's senior administrators and the Public Relations rewards cannot be wholly de-linked from the speed at which the medical school at the University of Limpopo was pre-maturely operationalised.

Burdening Health Insurance: Meanwhile, it is also interesting to note that in South Africa, a health insurance policy is expensive while a funeral cover policy is comparatively cheap. For instance, the lowest monthly premium for health cover is around R600 per person (depending on the benefits)(Bonitas, 2015). On the other hand,it is possible to secure a funeral cover policy for as little as R120.00 per person (but also depending on age and benefits)(Clientele Life Insurance, 2015).What can be deduced from this contradiction is that while South Africa's government and the private sector seem to be concerned about giving decent funerals to the people, there is a small premium for preserving their health conditions.By logical corollary, this unfortunate trend should be worrying to all; considering the fact that health is a crucial pillar of socioeconomic development. The irony is that while South Africa is internationally lauded for having one of the best Constitution and laws, especially in terms of guaranteeing people's rights, with a ranking of 131st, its workforce is undoubtedly one of the unhealthiest globally(World Health Organisation, 2015). 
It is interesting to note that South Africa's developmental state is modelled along China, where it takes only 10 minutes to see a medical doctor in a private health facility (Xi, 2014). This is a situation that is highly commendable about the communist society of China and which is hardly observable in African countries, including South Africa. In contrast, the depth of the disappointing state of South Africa's health system is also reinforced by the fact that in South Africa, as it is with many African states, pizza delivery is often faster than an emergency callout for an ambulance. A narrow view of the sorry state of South Africa's health sector attributes this to rampant corruption. However, a sober reflection of the state of governance in South Africa vis-à-vis China shows that corruption knows no boundaries. In fact, corruptionin China is rife or worse than in African countries. To add to this heated scholarly and policy discourse, Nkondo (2012) observes that:

Corruption knows no bounds. It does not disappear as economies grow. Instead, it assumes new forms. For corruption is symptomatic of a deeper systemic problem, the failure of the public-private-partnerships that African governments have sought to mediate the contradictory claims of democracy and the market, a failure that has created a virtual collusive system between political and business elites.

Confused declarations: Central to the problems faced by post-independent African states is the tendency to make 'declarations without real action'. Moreover, the deplorable working conditions in most African states naturally pushes medical doctors and other health professionals to go and serve in countries such as Australia, US and Britain. Unfortunately, this trend results in brain drain for South Africa and other African countries. But it can also be understood as 'brain gain' for the receiving industrialised countries. It is therefore not surprising that globally, Africa has the second-worst shortage of health workers at 4.2 million, compared to Europe's 100,000 (World Health Organisation, 2017). Despite the complex web of political and socioeconomic challenges faced by South Africain particular and Africa in general, the exiled President of the ANC, Oliver Tambo (as cited by(Pahad, 2014, p. 80) advises that "[T]o be true to history, we must concede that there have been difficulties as well as triumphs along our part ...".Flowing from this, it is indeed necessary to appreciate the achievements regarding South Africa's political transition. However, itmust also be honestly acknowledged that there are persistent challenges in health, economy, and society in general. Sadly, in the recent past, several leaders of African states have died either in domestic private hospitals or outside their countries in their search for better health service. Examples include Michael Sata of Zambia who died in Britain; Umaru Yar' Adua passed away in 2010 after months of hospitalisation in Saudi Arabia; Meles Zenawi of Ethiopia died in Belgium while the former President of South Africa, N. Mandela died a few months after being discharged from Mill Park private hospital. In relation to this, Motshegoa (2014)accounts that the recent death of Michael Sata brings 'the number of African presidents dying in foreign hospitals to nine'.As Kazeem (2017)notes, "Indeed, in the last decade, six of the 12 African leaders who have died while in office did so while seeking treatment abroad". It is the conviction of this article that the passing away of most African leaders outside their countries and/or in private hospitals is a tragic acknowledgment of their inability and/or unwillingness to adequately address the health needs and demands of their down-trodden and impoverished civilian populace.

Table 2: African Presidents that died in foreign private hospitals

\begin{tabular}{lll}
\hline President & Country & Died \\
\hline Michael Sata & Zambia & London (2014) \\
MalamBacaiSanhá & Guinea Bissau & France (2012) \\
MelesZenawi & Ethiopia & Belgium (2012) \\
Omar Bongo & Gabon & Spain $(2009)$ \\
Levy Mwanawasa & Zambia & France (2008) \\
BinguwaMutharika & Malawi & South Africa (2013) \\
\hline
\end{tabular}

Source: Kazeem (2017)

The preceding narrative of the sad reality of the status quo of African health sector affirms this article's argumentthat inadequate health services in the public sectordeny the majority of people the opportunity to enjoy their health rights and human rights broadly. Historicising the negative state of health in South Africa and elsewhere in the continent reflects a mixed bag of both internal and external factors. These factors have contributed to the appalling situation (Chazan, 1988). At the root of this problem is neo-colonialist tendencies, championed by the West, to the disadvantage of African nations. For example, in the post- 
independence era, most African states signed some agreements with the West, which continue to deprive the African masses of what is due to them. An example are the agreements that have produced the unpopular Structural Adjustment Programmes (SAPs) and Poverty Reduction Papers (PRPs) of both the International Monetary Fund (IMF) and World Bank, which have further deepened Africa's developmental crisis as opposed to their envisaged goals(Shai, 2013). These agreements have provided a safe passage for African states to access foreign aid (either in the form of loans or grants), but with stifling conditions. This aidwas meant to help Africa address its political, economic and social problems. However, conditional aid has generally failed to emancipate Africa from the shackles of poverty and under-development. Hence, foreign aid has been abused by the West to eschew the policy content and direction of many of the African states towards a particular agenda. Often this agenda does not serve the interests of the local people. In post-apartheid South Africa, for example, the Mandela Administration was compelled by the Western capitalist donors to ditch the socialist orientated Reconstruction and Development Programme (RDP), as the macroeconomic policy framework of the country(Shai, 2009). As a result, in 1996 the ANC-led government switched the RDP in favour of the more liberal flavoured Growth, Employment, and Redistribution (GEAR) strategy to please the West and ultimately gain foreign investor confidence.

As in other African countries, South Africa's decision to conform to demands of the globalising economy has literally undermined the legitimate aspirations of the locals to receive adequate health care. Hence, South Africa's government was discouraged by the donor community from making huge investments to provide free social services such as adequate health care and decent education. Consequently, there is an evolving contradictory trend which has produced a crisis in public health services for the majority and decent private health services for the few, privileged minorities ${ }^{3}$ suggest that human rights have been commodifiedin the new South Africa. Undoubtedly, skewed imbalances in spending in both private and public sectors has led to increased costs and adversely affected the distribution of services. This has further conscripted the delivery and guarantee of socioeconomic human rights of the people, as provided for in the Constitution (National Planning Commission, 2012). This article further argues that progress inthe recognition ofinternational human rights must transcend beyond the ratification of international treaties and regimes. In addition, more attention needs to be focused on the massive population of the African people that remain secluded from decent health care delivery as a result of prevailing neo-liberal imperatives that dictate national priorities. Thistherefore calls for a need to secure the acceptance of health and reproductive rights as critical components of human rights.

Clearly, as Evans (2000) also believes, the dominant discourse in the international literature is still staged by a liberal consensus on human rights. Thus the securitization of health in Africa can only be guaranteed when the physical health conditions of its people improve in ways that equally progress their socioeconomic conditions. This Afrocentric narrative perhaps presents a critical alternative argument on the discourse of health as a human right, which is often silenced in popular literature on public health and human rights. Surely, the right to health cannot remain an aspirational claim to human rights, as the liberal consensus school wants us to believe. However, the health consequences of globalisation brought about by the liberal, free market economy continues to dictate "health markets, technologies, science, drugs and the global organisation of business and finance", to the detriment of Africa(Evans, 2002, p. 213). Pointedly, the intervening features of today's globalised world persist in forms that limit Africa's capacity to secure the socioeconomic rights of its people especially in the area of health care. As Evans (2002, p. 213)concedes, "Like all other socioeconomic rights, the right to health cannot be realised unless the institutions of the current global order have the capacity to intervene in the activities of those who currently exercise their freedoms to increase their wealth, no matter the social conditions that others must suffer". To this end, (reproductive) health rights of women must be safeguarded through policy initiatives and adequate budgetary allocation. It is in this context that the World Population Report (2017) calls for the development of legislation on affirmative action, to ensure the prioritization of women's human rights, especially in Africa. Affordability and equality in health care support will continue to remain a huge problem for South Africa and indeed the rest of Africa, until critical reforms are introduced which prioritize Africa and holistically cater for the massive black

\footnotetext{
${ }^{3}$ The NDP 2030 reports that the country's public sector serves 83 percent $(41.7$ million) of the population compared to the private sector's 17 percent (8.3 million) (NPC, 2012).
} 
population that remains in the periphery of health care delivery. Critical to this is the need to comprehensively address the socio-economic determinants that affect health care delivery in South Africa.

\section{Conclusion and Policy Implications}

In the final analysis, it is needless to mention that in the new democratic dispensation, South Africa has been able to steer the political transition successfully. This is due to the reasons outlined in this article; namely, that the South African government has not been able to revolutionizeits society, including the health sector. As such, human rights are not equally enjoyed by all, as envisaged in the Constitution. While institutionalized racism has been officially abolished in the early 1990s, its manifest challenges continue to persist to date, and remain evident in gaining access to health care. This limitation must be understood within the context that the majoritarian poor and downtrodden civilian populace are still subjected to poor conditions of health services in the public sector while the minority segment of the middle class and wealthy people (who are mostly white) have unparalleled access to decent health services in private facilities. To this end and no matter what the dictates of the international economic and political system project, it is quite important for South Africa to engage robustly on the mobilisation of both economic and human resources, to effectively address its health crisis and enforce equity in the provision of health services. This is a measure that will go a long way in ensuring that the South African state lives up to the people's rights, as enshrined in its Constitution. Lastly, the critical study of this article has revealed that South Africa's health system still faces challenges relating to financing inequalities, health literacy and inter alia. Equally, there have been improvements in terms of health infrastructure and access to primary health care. Therefore, based on the combination of the above, it is safe to state that South Africa's human rights record in the health sector is at crossroads, but more still needs to be done.

Based on the findings of this study, the following policy recommendations are proposed for consideration by decision makers:

- There is an urgent need for the establishment and tangible support for domestic pharmaceutical companies which will prioritise the needs and interests of the local masses, as compared to their commercially-driven and exploitative Western counterparts.

- While it is useful for South Africa to benchmark globally, it is also important to contextualise such in the African continent, with countries that have common political and socio-economic history with the former.

- Practical measures to contain the scourge of systemic corruption must be considered. This is because corruption eats away from budgets meant to benefit the masses for the benefit of the politically connected few.

- Government must re-prioritize health as a critical aspect of national well-being in terms of quality, budgeting, skills development, recruitment and retention.

- Tangibly criminalise the collusion between the political and business elites in view of gradually untangling democracy from the market.

- Decision makers must be flexible enough to embrace African-centred, emerging and alternative ways of viewing, thinking and acting.

- As a socio-economic right, health must be elevated to the status of civil and political rights that warrant international intervention whenever they are seriously abused.

- Finally, it is strategically and ideologically crucial for [South] African decision makers to transcend political populism in order to stay relevant to the transformation agenda of their society.

\section{References}

Alkebulan, A. A. (2007). Defending the paradigm. Journal of Black Studies, 37(3), 410-427.

Asante, M. (2003). Afrocentricity: The theory of social change: African American Images: Chicago, Illinois, US.

Barlow, P. (1999). Health care is not a human right. BMJ: British Medical Journal, 319(7205), 321.

Bonitas. (2015). Product offering.

Chazan, N. (1988). Politics and society in contemporary Africa / Naomi Chazan ... [et al.]. Houndmills, Basingstoke, Hampshire: Macmillan. 
Clientele Life Insurance. (2015). Affordable Funeral Cover [Press release]. Retrieved from http://www.clientelelifeinsurance.co.za/?sourceID=3\&campaignID=10

DEA. (2013). Annual Report. Retrieved from Pretoria:

Dunn, W. N. (2015). Public policy analysis: Routledge.

Durojaiye, E. T. \& Mirugi-Mukundi, G. (2015). The ebola virus and human rights concerns in Africa. African journal of reproductive health, 19(3), 18-26.

Dzimiri, P., Runhare, T., Dzimiri, C. \& Mazorodze, W. (2014). Naming, identity, politics and violence in Zimbabwe. Studies of Tribes and Tribals, 12(2), 227-238.

Evans, T. (2002). A human right to health? Third World Quarterly, 23(2), 197-215.

Heywood, M. \& Cornell, M. (1998). Human rights and AIDS in South Africa: from right margin to left margin. Health and Human Rights, 3, 60-82.

Kahn, K. (2011). Population health in South Africa: dynamics over the past two decades. Journal of public health policy, 32(1), S30-S36.

Kazeem, Y. (2017). Africa's presidents keep going abroad for medical treatment rather than fixing healthcare at home. Quartz Africa.

Litch, R. \& de Villiers, B. (1994). Introduction. In R. L. a. B. d. Villiers (Ed.), South Africa's Crisis of Constitutional Democracy (pp. 1-17). Washington: AEI Press.

Maake, M. (2009). The Darfur conflict: Reflections on the state of human security since 2003. Unpublished BA Hons (IR) mini-dissertation. Thohoyandou: University of Venda.

Maleka, M. S. \& Shai, K. B. (2016). South Africa's post-apartheid foreign policy towards Swaziland. Journal of Public Administration, 51(2), 194-204.

Mazama, A. (2003). The afrocentric paradigm: Africa World Pr.

Modupe, D. S. (2003). The Afrocentric philosophical perspective: A narrative outline. The Afrocentric paradigm, 2, 55-72.

Motshegoa, T. (2014). The Sad reality of African affairs.Sowetan

National Planning Commission, NPC. (2012). National Development Plan 2030: Our future-make it work. Pretoria: National Planning Commission.

Nkondo, M. (2012). Setting the platform for 2014 elections-Born frees learning from veterans: Talking about the future of fundamental change in South Africa. Paper presented at the Seminar organised by the Independent Electoral Commission (IEC), Polokwane.

Onyeani, C. (2012). Capitalist Nigger: The Road to Success: A Spider Web Doctrine: BookBaby.

Pahad, A. (2014). Insurgent Diplomat-Civil Talks or Civil War? : Random House Struik.

Poopedi, T. M. (2014). Re-evaluating the African Union's role in resolving conflicts: A case study of Libya. (Masters), University of Limpopo.

Quintal, G. (2016). New medical school opens in Limpopo. News24. Retrieved from https://www.news24.com/SouthAfrica/News/new-medical-school-opens-in-limpopo-20160216

Richards, D. (1979). The ideology of European dominance. Présence africaine, 3, 3-18.

Shai, K. B. (2009). Rethinking United States-South Africa Relations. Hoedspruit: Royal Batubatse Foundation.

Shai, K. B. (2010). The United State of America's foreign policy towards Africa: The case studies of Kenya and Nigeria, 1990-2008. (MA Masters), University of Venda, Limpopo.

Shai, K. B. (2013). A Reader: Public Policy Analysis. Sovenga: University of Limpopo.

Shai, K. B. \& Molapo, R. R. (2017). The "Decriminalisation" of the \#FeesMustFall Movement in South Africa: An Asantean Perspective. Commonwealth Youth and Development, forthcoming.

Shai, K. B. \& Mothibi, K. A. (2015). Describing pre-2009 Xenophobic Violence in South Africa: A Human Right Perspective. Paper presented at the African Governance: Society, Human Migration, State, Xenophobia and Business Contestations, The Ranch Resort, South Africa.

World Health Organisation, WHO. (2015). A Universal Truth: No Health Without a Workforce. Retrieved from http://www.who.int/workforcealliance/knowledge/resources/GHWA-a_universal_truth_report.pdf

World Health Organisation, WHO. (2017). Estimates of health workers needs-based shortages by WHO region, 2013. Retrieved from http://www.who.int/gho/health_workforce/hrh_012.jpg?ua=1

Xi, J. (2014). The governance of China: Foreign Languages Press. 